\title{
Selected Physicochemical Properties of Registered Clones and Wild Types Rambutan (Nephelium lappaceum L.) Fruits and Their Potentials in Food Products (Sifat Fizikokimia Terpilih Klon Berdaftar dan Buah Rambutan Jenis Liar \\ (Nephelium lappaceum L.) serta Potensinya dalam Produk Makanan)
}

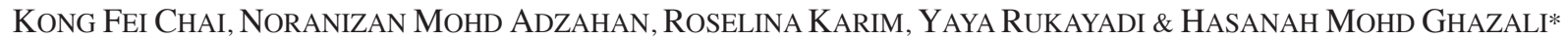

\begin{abstract}
Rambutan fruit is an exotic fruit and is getting popular worldwide. However, there is usually a glut of rambutan fruit every year which leads to wastage, especially those from underutilized wild types. Transforming the fruit into various products could reduce the wastage. Before doing so, the characteristics of the fruit should be available. Hence, the main aim of this study was to investigate the physicochemical properties of various cultivars of rambutan. The results showed that rambutan fruit comprises between 38.6-70.8\% peel, 19.1-45.9\% pulp and 8.3-20.3\% seed. On average, it has a pH, titratable acidity and total soluble solids of 4.18-5.44, 0.10-0.52\% as citric acid and 13.78-16.67 ${ }^{\circ}$ Brix, respectively. The fruit contains high sugar contents, mainly contributed by sucrose (5.38-10.01\%), fructose (1.75-3.18\%) and glucose (1.72-2.43\%). Citric acid was the major organic acid found in the fruit and wild type, WT1, contained the highest level. Some rambutan cultivars including Clone R3, WT1 and wild type, WT2, possess greater concentrations of ascorbic acid compared to other tropical fruits. With these findings, various types of food products could be derived from rambutan fruit based on their physicochemical properties.
\end{abstract}

Keywords: Organic acids; proportion of different parts of fruit; pulp-to-seed ratio; sugars

\section{ABSTRAK}

Rambutan adalah sejenis buah eksotik yang semakin popular di serata dunia. Tetapi, bekalan buah rambutan yang berlebihan terutamanya rambutan jenis liar telah menyebabkan pembaziran setiap tahun. Transformasi buah rambutan kepada pelbagai produk dapat mengurangkan pembaziran. Namun, ciri-ciri buah perlu diketahui sebelum transformasi dilakukan. Oleh itu, objektif kajian ini adalah untuk menentukan ciri fizikokimia pelbagai kultivar rambutan. Keputusan kajian menunjukkan rambutan terdiri daripada 38.6-70.8\% kulit, 19.1-45.9\% isi dan 8.3-20.3\% biji. Rambutan mempunyai pH4.18-5.44, keasidan titrat sebanyak 0.10-0.52\% asid sitrik dan jumlah pepejal terlarut sebanyak 13.78-16.67 ${ }^{\circ}$ Brix. Buah rambutan mengandungi kandungan gula yang tinggi dan terdiri daripada sukrosa (5.38-10.01\%), fruktosa (1.75-3.18\%) dan glukosa (1.72-2.43\%). Asid sitrik ialah asid organik utama yang terdapat dalam buah rambutan dan rambutan jenis liar, WT1 mengandungi kandungan asid sitrik yang tertinggi antara semua kultivar rambutan yang dikaji. Beberapa kultivar rambutan termasuk buah rambutan Klon R3, WT1 dan rambutan jenis liar, WT2, mengandungi asid askorbik yang lebih tinggi berbanding buah tropika lain. Keputusan menunjukkan kultivar rambutan yang berbeza mempunyai ciri fizikokimia yang berlainan dan pelbagai jenis produk makanan dapat dihasilkan berdasarkan ciri fizikokimia masing-masing.

Kata kunci: Asid organik; gula; nisbah isi-ke-biji; perkadaran buah pada bahagian yang berbeza

\section{INTRODUCTION}

Rambutan (Nephelium lappaceum L.) is a popular tropical fruit from family Sapindaceae (Wall 2006). It is closely related to lychee (Litchi chinesis), pulasan (Nephelium mutabile Blume) and longan (Dimocarpus longan). It is a native of west Malaysia and the island of Sumatra (Indonesia) (Tindall 1994). The distinctive feature of rambutan fruit is its colored skin and spinterns (hairs). The color of the skin ranges from red to yellow. The edible portion of the fruit (pulp) is a fleshy, translucent-white sarcotesta which arises from a paper-like integument surrounding a single oblong seed (Goenaga 2011). The pulp tastes sweet and sour with registered clone fruits having sweeter pulp compared to wild type fruits. The pulp is similar in flavor to a lychee, although less aromatic, while the texture is relatively firmer and less juicy (O'Hare 1995). In 'freestone' cultivars, the sarcotesta and integument come freely away from the seed, while in 'clingstone' cultivars they are more difficult to separate.

Rambutan is an important commercial crop in Asia where it is normally consumed fresh, canned or processed and appreciated for its refreshing flavor and exotic appearance. In Malaysia and Thailand, rambutan is industrially processed into juice, jam, jelly, marmalade and spread (Morton 1987). In addition, the fruits are also processed as rambutan stuffed with a chunk of pineapple 
and canned in syrup (Sirisompong et al. 2011). Freezedried rambutan chips are found in the market as well. During rambutan harvest season, the fruit is easily available throughout the nation. However, the fruit is susceptible to rapid deterioration (3-4 days at ambient temperature, or a few weeks at $12-13^{\circ} \mathrm{C}$ and $90-95 \%$ relative humidity) (Siriphanich 2003). Hafiz et al. (2017) suggested that combination of hot water treatment, oxalic acid dip and modified atmosphere packaging could retain the firmness and color of the fruit. Since the fruit deteriorates rapidly, there is much waste when supply of the fruit, especially the wild type, exceeds demand. The massive amount of the excessive fruits being discarded causes a severe problem in the community as they gradually ferment and release off-odors. A more in depth knowledge of the fruit will encourage its consumption in diverse ways and thus, wastage of the fruit could be reduced or eliminated.

Arenas et al. (2010) reported that rambutan fruit weight ranges from 22.4 to $34.7 \mathrm{~g}$, registering from 28.9 to 45.0 fruits per $\mathrm{kg}$. The fruit is composed of 45.9 to $49.9 \%$ rind, 37.5 to $41.4 \%$ pulp and 7.0 to $10.0 \%$ seed. The sugars in rambutan pulp are composed mainly of sucrose $(9.9 \mathrm{~g} / 100$ $\mathrm{g})$, fructose $(3.0 \mathrm{~g} / 100 \mathrm{~g})$ and glucose $(2.8 \mathrm{~g} / 100 \mathrm{~g})$ (Tindall 1994). Lee et al. (2013) reported that the most dominant organic acid in rambutan pulp is citric acid. Other organic acids present are tartaric, malic, succinic and lactic acids.

Although there are many rambutan clones that have been registered with the Ministry of Agriculture and AgroBased Industry Malaysia, the physicochemical properties of the fruit, especially the underutilized wild types remained unknown. More importantly, prior to transforming the fruit into various products, the fundamental knowledge of the fruit should be understood as different fruit cultivar possesses different characteristics. Therefore, the objective of this study was to determine the physicochemical properties of nine registered clones and two wild types of rambutan fruits.

\section{MATERIALS AND METHODS}

All rambutan fruit samples were obtained from the University Agricultural Park, Universiti Putra Malaysia (UPM). Eleven cultivars of ripe rambutan fruits, namely R3, R4, R7, R10, R153, R156, R169, R191, Sarjan and 2 wild types (WT1 and WT2) were collected. For each clone or type, fruits for analysis were those that were free of blemishes and were of uniform color and size. Two batches of samples (obtained from two different fruiting seasons) were used in this study. Each batch was analyzed in triplicate.

One kilogram of freshly harvested rambutan fruit (matured and ready for consumption) for each cultivar was used to determine their relative percentages of peel, pulp and seed. The peel, fruit pulp and seeds were separated from each fruit and pooled peel, pulp and seeds weighed separately. The results were expressed as relative percent and pulp-to-seed ratio based on the following formulae, respectively.
The $\mathrm{pH}$, titratable acidity (TA) and total soluble solids (TSS) were determined according to the method described by Ranganna (1977). The results of TA and TSS were expressed as $\%$ citric acid and ${ }^{\circ}$ Brix, respectively.

The sugar profile and content of the samples were obtained using High Performance Liquid Chromatography (HPLC) and analysis was performed using a Waters 2695 Alliance HPLC (Waters Corp., Milford, MA, USA) connected to a Waters 2414 refractive index (RI) detector, two Waters 515 HPLC pumps, an auto-sampler and an online degasser. The chromatographic column used for separation was a Purospher ${ }^{\circledR}$ Star $\mathrm{NH}_{2}$ column $(259 \mathrm{~mm} \times 4.6 \mathrm{~mm}$, particle size of $5 \mu \mathrm{m}$ from Merck, Darmstadt, Germany) connected to a Purospher ${ }^{\circledR} \mathrm{NH}_{2}-18 \mathrm{e}$ guard column $(4 \times 4 \mathrm{~mm}$ I.D from Merck, Darmstadt, Germany), thermostated at $35^{\circ} \mathrm{C}$ (Hunt et al. 1977). The injection volume was $10 \mu \mathrm{L}$. The eluent used in this analysis was degassed HPLC-grade acetonitrile and deionized water $(80 / 20, \mathrm{v} / \mathrm{v})$ and the flow rate was at $1.5 \mathrm{~mL} / \mathrm{min}$.

For extraction of sugar, $10 \mathrm{~g}$ of homogenized fruit sample was treated with $100 \mathrm{~mL}$ of $85 \%$ methanol for 30 min at $80^{\circ} \mathrm{C}$ in a water bath. The sample was then filtered through a Whatman No. 1 filter paper and the sample residue was then re-extracted twice as previously above using a total of $75 \mathrm{~mL}$ of $85 \%$ methanol. The filtrates were pooled and the volume was reduced in a rotary vacuum evaporator and finally made up to $10 \mathrm{~mL}$ with deionized water. The solution was then filtered through a Sep-Pak C18 cartridge followed by $0.45 \mu \mathrm{m}$ membrane filters (Sartorius, Gottingen, Germany) and a $10 \mu \mathrm{L}$ sample was injected into the HPLC. Three sugar standards (glucose, fructose and sucrose from Sigma Aldrich (St. Louis, MO, USA) with concentration ranging from $0-8 \%(\mathrm{w} / \mathrm{v})$ were used to identify and quantify the sugars present in the rambutan samples. These standards were also analyzed using HPLC under the same conditions as for samples. To obtain the standard curve for each sugar, the peak areas were plotted against the corresponding concentrations in final solution injected to HPLC.

Organic acid analysis was carried out by referring to the method described by Sturm et al. (2003) with slight modifications. The HPLC system and software used in this analysis were similar to those used for sugar analysis but with a different detector (Waters 2478 two-channel UV detector). A Purovspher® Star RP18 end-capped column (250 mm $\times 4.6 \mathrm{~mm}$ I.D., $5 \mu \mathrm{m}$ particle size, from Merck, Darmstadt, Germany) connected to a Purovspher ${ }^{\circledR}$ RP18 e guard column $(4 \times 4$ mm I.D from Merck, Darmstadt, Germany) and thermostated at $30^{\circ} \mathrm{C}$. Degassed $0.008 \mathrm{M}$ $\mathrm{H}_{2} \mathrm{SO}_{4}$ was used as the mobile phase for separation of organic acids in rambutan pulp and the flow rate was at $0.5 \mathrm{~mL} / \mathrm{min}$ (Sturm et al. 2003).

Extraction of organic acids was carried out by making a $50 \mathrm{~mL}$ suspension of $10 \mathrm{~g}$ of homogenized sample with deionized water which was then clarified by centrifugation at $6000 \times \mathrm{g}$ for $15 \mathrm{~min}($ Beckman J2-21M/E, USA) (Medlicott \& Thompson 1985; Sturm et al. 2003). The extract was filtered through a $0.45 \mu \mathrm{m}$ membrane filters 
(Sartorius, Gottingen, Germany) and a $10 \mu \mathrm{L}$ of sample was injected into the HPLC. Detection of organic acids was done at $210 \mathrm{~nm}$. Five organic acids, namely lactic acid ( $85 \%$ purity, JT. Baker, Central Valley, USA), tartaric acid (99\% purity) and citric acid (99\% purity) (all from Fisher Scientific, Rochester, NY, USA), malic acid (99\% purity) and ascorbic acid (99\% purity) (both from Sigma Aldrich, St. Louis, MO, USA) were used to obtain standard curves. The concentrations of the standard organic acid solutions ranged from $0.02-0.10 \%$, obtained by serial dilution of $0.10 \%$ stock solutions. Organic acids of the samples were identified and quantified by comparison of retention times and peak areas with standard organic acid solutions.
The analytical data were analyzed by one-way analysis of variance followed by Tukey's test using Minitab v. 16 Statistical Software (Minitab Inc., Coventry, UK). The results were expressed as mean value \pm standard deviation. Statistical significance differences were considered at the level of $p<0.05$.

\section{RESULTS AND DISCUSSION}

Figure 1 shows the representative images of eleven cultivars of rambutan fruit under study. The relative percent of different parts of the fruits is shown in Table 1. As can be seen, there are significant differences $(p<0.05)$ in the

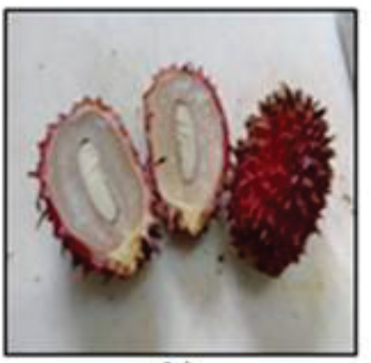

(a)

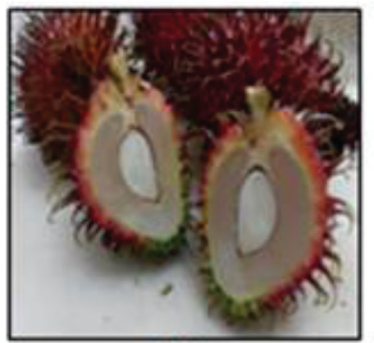

(d)

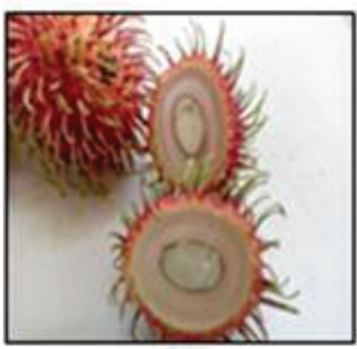

(g)

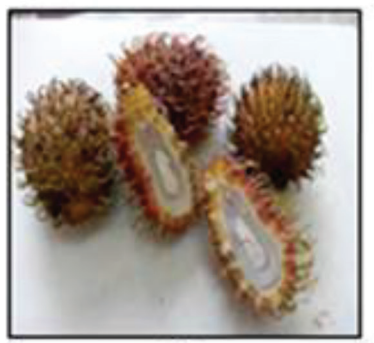

(j)

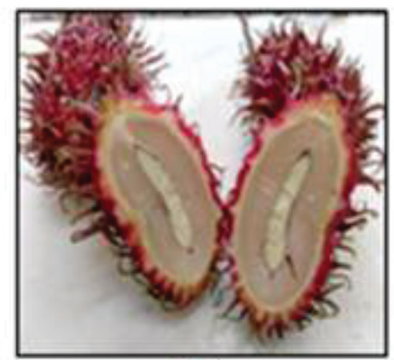

(b)

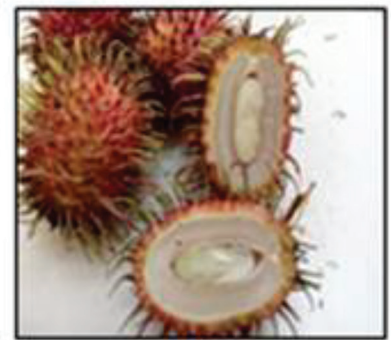

(e)

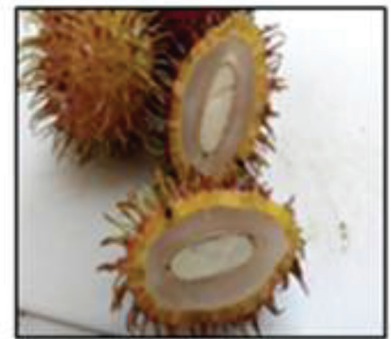

(h)

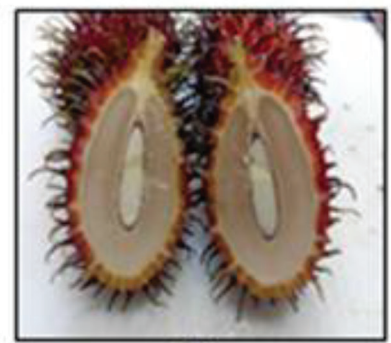

(k)

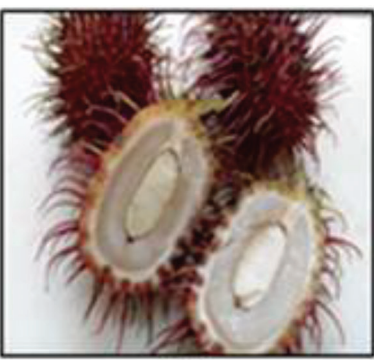

(c)

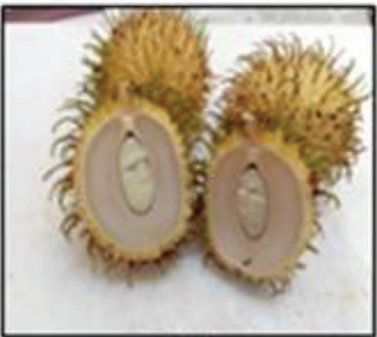

(f)

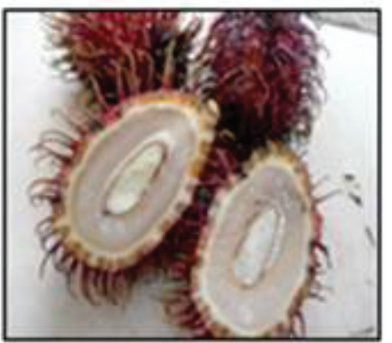

(i)

FIGURE 1. Different cultivars of rambutan used in the study, namely (a) Clone R3, (b) Clone R4, (c) Clone R7, (d) Clone R10, (e) Clone R153, (f) Clone R156, (g) Clone R169, (h) Clone R191, (i) Clone Sarjan, (j) cultivar WT1 and (k) cultivar WT2 


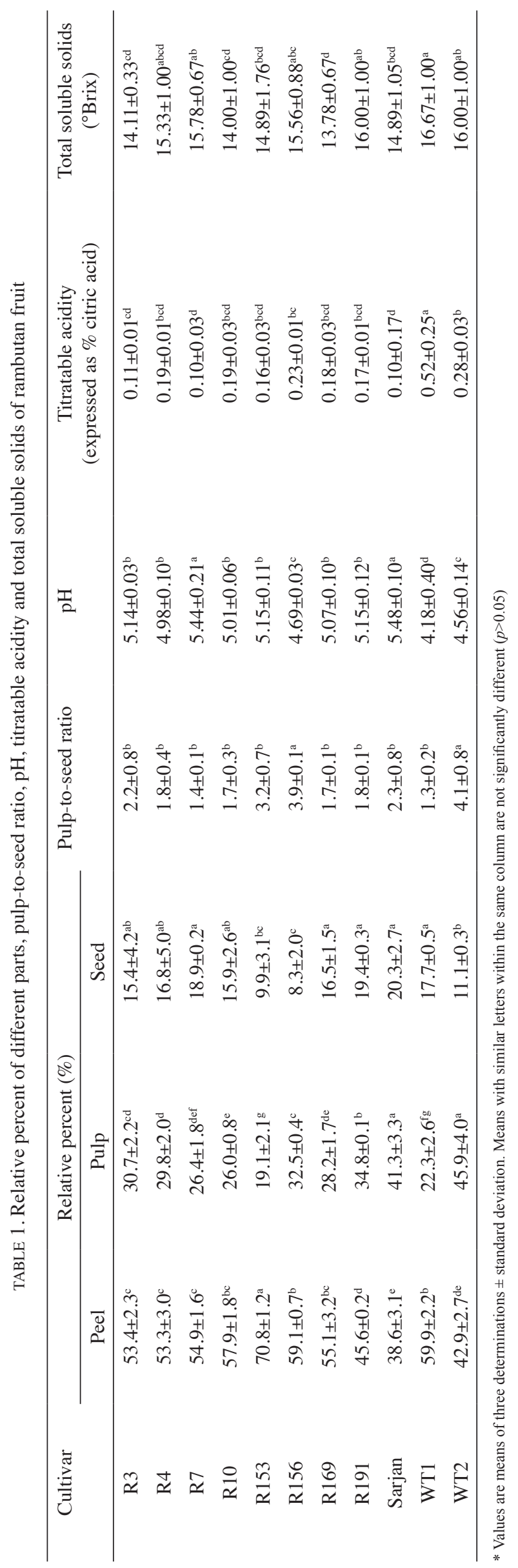


peel, pulp, seed and pulp-to-seed ratio among the rambutan cultivars. On average, a rambutan fruit comprised between $38.6-70.8 \%$ peel, $19.1-45.9 \%$ pulp and $8.3-20.3 \%$ seed while the pulp-to-seed ratio of rambutan fruit ranged between 1.4 and 4.1. Although WT2, a wild type cultivar, had the highest percentage of pulp (45.9\%), it was not statistically different from that of Clone Sarjan (41.3\%). However, the pulp proportion of rambutan WT2 was at least two times greater than that of Clone R153 (cultivar which had the lowest percentage of pulp, $19.1 \%$ and was not statistically different from that of rambutan WT1,22.3\%). Rambutan cultivars with low proportion of pulp indicate that they have high percentage of waste (peel and seed). On the other hand, rambutan Clone Sarjan and Clone R156 had the highest and lowest percentage of seed, respectively. The results shown in Table 1 are slightly different from the findings reported by Augustin and Chua (1988) who found that the rambutan seeds of Clone R4, R7 and R169 they studied were made up of 6.3-8.8\% of the weight of the fruits. $\mathrm{Ng}$ and Thamboo (1967) found that the rambutan fruit they studied was composed of $47.5 \%$ peel, $46.1 \%$ pulp and $6.3 \%$ seed. These differences are likely due to the differences in cultivars.

In this study, rambutan Clone R153 had the highest percentage of peel and is suitable to be used in the production of medicinal products as the peel extract is reported to possess antioxidant (Fidrianny et al. 2015), antibacterial (Leong \& Shui 2002; Palanisamy et al. 2008; Thitilertdecha et al. 2008) anticancer (Okonogi et al. 2007), antidiabetic and antihypercholesterolemic (Suhendi \& Muhtadi 2015) activities. On the other hand, wild type cultivar WT2 appeared to have the highest proportion of pulp compared to the registered clones and this phenomenon is unusual to be seen in a wild type cultivar. WT2 is a type of clingstone fruit (its pulp adheres strongly to its seed) which indicates that it is a wild type. Moreover, this cultivar had the highest percentage of pulp is possibly due to the fact that it was served as the mother during the breeding of the fruit. WT2 and Sarjan cultivars are better for canning or being used in food products requiring a higher quantity of pulp such as jam, juice and chips because they had higher percentage of pulp compared to the other cultivars. Besides, Clone Sarjan would also be suitable for fat extraction because it had the highest percentage of seed and based on the range of fat in rambutan seed (38-41\%) (Manaf et al. 2013; Winayanuwattikun et al. 2008)the aim of the study was to determine the physicochemical properties of this fat for potential applications. The iodine and saponification values, and unsaponifiable matter and free fatty acid contents of the seed fat were $50.27 \mathrm{~g} \mathrm{I} / 100 \mathrm{~g}$ fat, $182.1 \mathrm{mg} \mathrm{KOH} / \mathrm{g}$ fat, $0.8 \%$ and $2.1 \%$, respectively. The fat is pale yellow with a Lovibond color index of $3.1 \mathrm{Y}+1.1 \mathrm{R}$. The fatty acid profile indicates an almost equal proportion of saturated $(49.1 \%$, it is likely to contain a high quantity of fat. Similar observation was reported by Augustin and Chua (1988) who found that among the three clones of rambutan they studied (R4, R7 and R169), Clone R7 had the highest percentage of seed and crude fat content. The fat is edible and some studies showed that the fat can be used also for manufacturing of candles, soaps and fuels (Morton 1987; Zee 1993). Manaf et al. (2013) suggested that the rambutan seed fat could be used in the high premium specialty fats. Blending the rambutan seed fat with a softer oil or harder fat may lead to products with wider usage.

$\mathrm{pH}$ and titratable acidity (TA) are related to each other, and together with total soluble solid (TSS) contents, are important properties of fruits, including rambutan. Table 1 shows the $\mathrm{pH}$, TA and TSS content of the rambutan fruit under study. As can be seen, there are significant differences $(p<0.05)$ in the $\mathrm{pH}$, TA and TSS among the rambutan cultivars. Clone Sarjan has the highest $\mathrm{pH}$ while WT1 has the lowest $\mathrm{pH}$, consistent with this cultivar having the highest TA (Table 1). The results are comparable with previous findings by Lee et al. (2013) who reported that the $\mathrm{pH}$ of the rambutan fruit they studied was $\sim \mathrm{pH} 5$. Bates et al. (2001) reported that $\mathrm{pH}$ of tropical fruits usually ranges from $\mathrm{pH} 3.23$ to 6.00 . The TA and TSS of rambutan fruit in this study are comparable to those reported by Lee et al. (2013). WT1 has the highest TSS content $(16.67 \pm 1.00$ ${ }^{\circ}$ Brix) among the 11 cultivars of rambutan, indicating the presence of high sugar (typically sucrose) content. The lower $\mathrm{pH}$ and higher TA and TSS in wild type rambutans show that they are more acidic and contain a higher sugar content compared to the registered clone rambutans. According to Lakshminarayana (1980), fruits with lower titratable acidity would normally have higher total soluble solids. However, results in this study showed that WT1 had the highest titratable acidity and total soluble solids, indicating that WT1 could have a good balance between acidity and sweetness. Hence, WT1 is suitable for jam production as sweet and sour tastes are the core flavors in jam.

Table 2 shows the sugar content of different cultivar of rambutan fruit. The main sugars found in the pulp of rambutan were glucose, fructose and sucrose which is in agreement with the studies reported by Lee et al. (2013) and Tindall (1994). Regardless of the cultivar, the total sugar of rambutan fruit pulp under study was composed mainly of sucrose $(5.38-10.01 \%)$, followed by fructose (1.75-3.18\%) and glucose (1.72-2.43\%), with Clone R153 having the highest sucrose concentration $(10.01 \%)$ while WT1 containing the highest glucose and fructose contents which were $2.43 \%$ and $3.18 \%$, respectively. Table 2 shows that there is no significant difference $(p>0.05)$ among the rambutan cultivar in terms of total sugar content. The highest total sugar content $(13.81 \%)$ was found in Clone $\mathrm{R} 4$, indicating that it is suitable to be produced into products which are sweet and contain high sugar content such as jam and jelly. The study also showed that both wild type fruits had high concentrations of sugars despite the fact that they tasted tart, and is in consonant with their higher titratable acidity values (Table 1). Selvaraj and Pal (1984) reported that due to the differential enzyme activities, different cultivars and species of fruits can have different glucose/fructose ratios and sucrose concentrations. 
TABLE 2. Sugar contents of rambutan fruit

\begin{tabular}{ccccc}
\hline Cultivar & Glucose $(\%)$ & Fructose $(\%)$ & Sucrose $(\%)$ & Total sugar $(\%)$ \\
\hline R3 & $2.08 \pm 0.61^{\mathrm{a}}$ & $2.25 \pm 0.61^{\mathrm{ab}}$ & $5.38 \pm 2.29^{\mathrm{b}}$ & 9.71 \\
R4 & $2.08 \pm 0.14^{\mathrm{a}}$ & $2.41 \pm 0.15^{\mathrm{ab}}$ & $9.32 \pm 0.26^{\mathrm{ab}}$ & 13.81 \\
R7 & $1.98 \pm 0.22^{\mathrm{a}}$ & $2.61 \pm 0.29^{\mathrm{ab}}$ & $6.14 \pm 1.23^{\mathrm{ab}}$ & 10.72 \\
R10 & $1.72 \pm 0.05^{\mathrm{a}}$ & $1.75 \pm 0.08^{\mathrm{b}}$ & $6.25 \pm 0.35^{\mathrm{ab}}$ & 9.72 \\
R153 & $1.88 \pm 0.14^{\mathrm{a}}$ & $1.91 \pm 0.10^{\mathrm{ab}}$ & $10.01 \pm 0.74^{\mathrm{a}}$ & 13.80 \\
R156 & $2.29 \pm 0.16^{\mathrm{a}}$ & $2.53 \pm 0.18^{\mathrm{ab}}$ & $7.71 \pm 0.41^{\mathrm{ab}}$ & 12.53 \\
R169 & $2.25 \pm 0.08^{\mathrm{a}}$ & $2.21 \pm 0.09^{\mathrm{ab}}$ & $7.65 \pm 0.29^{\mathrm{ab}}$ & 12.11 \\
R191 & $1.67 \pm 0.01^{\mathrm{a}}$ & $1.76 \pm 0.02^{\mathrm{ab}}$ & $9.51 \pm 0.39^{\mathrm{ab}}$ & 12.94 \\
Sarjan & $2.32 \pm 0.03^{\mathrm{a}}$ & $2.53 \pm 0.06^{\mathrm{ab}}$ & $7.38 \pm 0.56^{\mathrm{ab}}$ & 12.23 \\
WT1 & $2.43 \pm 0.21^{\mathrm{a}}$ & $3.18 \pm 0.14^{\mathrm{a}}$ & $6.01 \pm 1.40^{\mathrm{ab}}$ & 11.62 \\
WT2 & $2.27 \pm 0.30^{\mathrm{a}}$ & $2.42 \pm 0.35^{\mathrm{ab}}$ & $7.75 \pm 1.40^{\mathrm{ab}}$ & 12.44 \\
\hline
\end{tabular}

* Values are means of three determinations \pm standard deviation. Means with similar letters within the same column are not significantly different $(p>0.05)$

TABLE 3. Organic acid contents of rambutan fruit

\begin{tabular}{cccccc}
\hline Cultivar & $\begin{array}{c}\text { Citric acid } \\
(\mathrm{g} / 100 \mathrm{~g})\end{array}$ & $\begin{array}{c}\text { Tartaric acid } \\
(\mathrm{g} / 100 \mathrm{~g})\end{array}$ & $\begin{array}{c}\text { Malic acid } \\
(\mathrm{g} / 100 \mathrm{~g})\end{array}$ & $\begin{array}{c}\text { Lactic acid } \\
(\mathrm{g} / 100 \mathrm{~g})\end{array}$ & $\begin{array}{c}\text { Ascorbic acid } \\
(\mathrm{g} / 100 \mathrm{~g})\end{array}$ \\
\hline R3 & $0.29 \pm 0.06^{\mathrm{d}}$ & $0.03 \pm 0.00^{\mathrm{c}}$ & $0.05 \pm 0.00^{\mathrm{a}}$ & $0.27 \pm 0.04^{\mathrm{ab}}$ & $0.10 \pm 0.04^{\mathrm{ab}}$ \\
R4 & $0.30 \pm 0.07^{\mathrm{d}}$ & $0.03 \pm 0.01^{\mathrm{abc}}$ & $0.04 \pm 0.01^{\mathrm{a}}$ & $0.10 \pm 0.02^{\mathrm{cd}}$ & $0.05 \pm 0.00^{\mathrm{ef}}$ \\
R7 & $0.55 \pm 0.04^{\mathrm{b}}$ & $0.03 \pm 0.00^{\mathrm{abc}}$ & $0.05 \pm 0.02^{\mathrm{a}}$ & $0.05 \pm 0.01^{\mathrm{d}}$ & $0.01 \pm 0.00^{\mathrm{g}}$ \\
R10 & $0.42 \pm 0.02^{\mathrm{c}}$ & $0.03 \pm 0.00^{\mathrm{c}}$ & $0.07 \pm 0.02^{\mathrm{a}}$ & $0.24 \pm 0.02^{\mathrm{ab}}$ & $0.07 \pm 0.01^{\mathrm{bcde}}$ \\
R153 & $0.56 \pm 0.05^{\mathrm{b}}$ & $0.03 \pm 0.01^{\mathrm{abc}}$ & $0.05 \pm 0.00^{\mathrm{a}}$ & $0.22 \pm 0.01^{\mathrm{b}}$ & $0.04 \pm 0.01^{\mathrm{fg}}$ \\
R156 & $0.54 \pm 0.03^{\mathrm{b}}$ & $0.04 \pm 0.00^{\mathrm{ab}}$ & $0.05 \pm 0.01^{\mathrm{a}}$ & $0.28 \pm 0.05^{\mathrm{a}}$ & $0.06 \pm 0.02^{\text {def }}$ \\
R169 & $0.54 \pm 0.03^{\mathrm{b}}$ & $0.03 \pm 0.00^{\mathrm{bc}}$ & $0.05 \pm 0.00^{\mathrm{a}}$ & $0.15 \pm 0.02^{\mathrm{c}}$ & $0.07 \pm 0.01^{\text {cdef }}$ \\
R191 & $0.42 \pm 0.03^{\mathrm{c}}$ & $0.03 \pm 0.00^{\mathrm{bc}}$ & $0.04 \pm 0.00^{\mathrm{a}}$ & $0.14 \pm 0.01^{\mathrm{c}}$ & $0.07 \pm 0.00^{\text {cdef }}$ \\
Sarjan & $0.42 \pm 0.03^{\mathrm{c}}$ & $0.04 \pm 0.01^{\mathrm{a}}$ & $0.04 \pm 0.00^{\mathrm{a}}$ & $0.29 \pm 0.05^{\mathrm{a}}$ & $0.07 \pm 0.00^{\mathrm{bcd}}$ \\
WT1 & $0.68 \pm 0.04^{\mathrm{a}}$ & $0.03 \pm 0.00^{\mathrm{abc}}$ & $0.05 \pm 0.01^{\mathrm{a}}$ & $0.12 \pm 0.02^{\mathrm{c}}$ & $0.09 \pm 0.01^{\mathrm{bc}}$ \\
WT2 & $0.53 \pm 0.06^{\mathrm{b}}$ & $0.03 \pm 0.00^{\mathrm{abc}}$ & $0.05 \pm 0.00^{\mathrm{a}}$ & $0.14 \pm 0.02^{\mathrm{c}}$ & $0.13 \pm 0.01^{\mathrm{a}}$ \\
\hline
\end{tabular}

* Values are means of three determinations \pm standard deviation. Means with similar letters within the same column are not significantly different $(p>0.05)$

The organic acid and ascorbic acid contents of 11 cultivars of rambutan are tabulated in Table 3 . There are significant differences $(p<0.05)$ in all acids except for malic acid content. The major organic acid in the rambutan pulp was citric acid (0.29-0.68 g/100 g) which comprised $35.8-74.3 \%$ of the total organic acid while lactic acid (0.10-0.29 g/100 g), ascorbic acid (0.01-0.13 $\mathrm{g} / 100 \mathrm{~g})$, malic acid $(0.04-0.07 \mathrm{~g} / 100 \mathrm{~g})$ and tartaric acid $(0.03-0.04 \mathrm{~g} / 100 \mathrm{~g})$ were present in minor proportions. This result is in agreement with Lee et al. (2013) in terms of types of organic acid present, the only group of researchers that has reported on organic acids in rambutan. They reported that rambutan fruit contained citric acid $(0.552 \mathrm{~g} / 100 \mathrm{~mL})$, lactic acid $(0.459 \mathrm{~g} / 100 \mathrm{~mL})$, malic acid $(0.219 \mathrm{~g} / 100 \mathrm{~mL})$, succinic acid $(0.169 \mathrm{~g} / 100$ $\mathrm{mL}$ ) and tartaric acid (0.0064 g/100 mL). Tindall (1994) found that the edible portion of rambutan contained $0.05 \%$ malic acid and $0.31 \%$ citric acid. Cultivar WT1 has the highest citric acid content $(0.68 \mathrm{~g} / 100 \mathrm{~g})$, indicating that this cultivar is suitable to be produced into jam and pickles. The ascorbic acid content of rambutan fruit in this study is comparable to that reported by Wall (2006) which was $36.4 \mathrm{mg} / 100 \mathrm{~g}(0.036 \mathrm{~g} / 100 \mathrm{~g})$ while the Nutrient Composition of Malaysian Foods stated that the concentration is $80.4 \mathrm{mg} / 100 \mathrm{~g}(0.080 \mathrm{~g} / 100 \mathrm{~g})$ (Tee et al. 1997). Compared to other tropical fruits such as longan $(60.1 \mathrm{mg} / 100 \mathrm{~g})$ and lychee $(27.6 \mathrm{mg} / 100 \mathrm{~g}$ ) (Wall 2006), some cultivars of the rambutan fruit such as R3 and WT2 are good source of the vitamin and are suitable to be canned to increase their shelf life.

Although both wild type rambutan cultivars in this study contained high concentrations of sugars (Table 2 ), however, they also contained high concentrations of organic acids. For example, the citric acid in WT1 (0.68 $\mathrm{g} / 100 \mathrm{~g}$ ) was at least two times greater than that in R3 $(0.29 \mathrm{~g} / 100 \mathrm{~g})$ and $\mathrm{R} 4(0.30 \mathrm{~g} / 100 \mathrm{~g})$. Thus, it is possible that the high concentrations of organic acid contents in the wild types would successfully mask their sweet flavor and give a perception of a more acidic taste compared to the registered clones.

\section{CONCLUSION}

From the results obtained in this study, rambutan fruit has high concentrations of sugar and organic acids, providing it to have a balance of sweet and sour taste. Both wild type rambutans in this study had lower $\mathrm{pH}$ and higher titratable acidity and citric acid content compared to the registered clones, indicating that they are suitable to be produced into food products which are 
acidic in taste. By understanding the characteristics of each rambutan cultivar, the fruit can be produced into various products based on its physicochemical properties and thus, reducing the wastage of the fruit, especially the underutilized wild type cultivar. Besides, by producing numerous types of rambutan-derived products, the fruit can be promoted to a more international level and subsequently, accelerating the agriculture industry of the fruit producing countries.

\section{ACKNOWLEDGEMENTS}

The authors would like to thank Universiti Putra Malaysia for the research grant (02-02-12-2049RU, Vote 9362600) awarded to H.M. Ghazali and the Ministry of Higher Education, Malaysia for the MyBrain Scholarship awarded to K.F. Chai.

\section{REFERENCES}

Arenas, M.G.H., Angel, D.N., Damian, M.T.M., Ortiz, D.T., Díaz, C.N. \& Martinez, N.B. 2010. Characterization of rambutan (Nephelium lappaceum) fruits from outstanding Mexican selections. The Revista Brasileira de Fruticultura 32: 1098-1104.

Augustin, M.A. \& Chua, B.C. 1988. Composition of rambutan seeds. Pertanika 11: 211-215.

Bates, R., Morris, J. \& Crandall, P. 2001. Principles and practices of small- and medium-scale fruit juice processing. FAO Agricultural Services Bulletin 146: 177-188.

Fidrianny, I., Fikayuniar, L.I.A. \& Insanu, M. 2015. Antioxidant activities of various seed extracts from four cultivars of rambutan (Nephelium lappaceum) using 2,2-diphenyl-1picrylhydrazyl and 2,2'-azinobis(3-ethyl-benzothiazoline6-sulfonic acid) assays. Journal of Pharmacognosy and Phytochemical 7: 280-285.

Goenaga, R. 2011. Dry matter production and leaf elemental concentrations of rambutan grown on an acid ultisol. Journal of Plant Nutrition 34: 753-761.

Hunt, D.C., Jackson, P.A., Mortlock, R.E. \& Kirk, R.S. 1977. Quantitative determination of sugars in foodstuffs by highperformance liquid chromatography. Analyst 102: 917-920.

Lakshminarayana, A.S. 1980. Mango. In Tropical and Subtropical Fruits Composition, Properties and Uses, edited by Nagy S. \& Shaw P.E. Westport, Connecticut: AVI Publishing Inc. pp. 185-201.

Lee, P., Tan, R., Yu, B., Curran, P. \& Liu, S. 2013. Sugars, organic acids, and phenolic acids of exotic seasonable tropical fruits. Nutrition \& Food Science 43: 267-276.

Leong, L.P. \& Shui, G. 2002. An investigation of antioxidant capacity of fruits in Singapore markets. Food Chemistry 76: 69-75.

Manaf, Y.N.A., Marikkar, J.M.N., Long, K. \& Ghazali, H.M. 2013. Physico-chemical characterisation of the fat from redskin rambutan (Nephellium lappaceum L.) seed. Journal of Oleo Science 62: 335-343.

Medlicott, A.P. \& Thompson, A.K. 1985. Analysis of sugars and organic acids in ripening mango fruit (Mangifera indica L. var. Keitt) by high performance liquid chromatography. Journal of the Science of Food and Agriculture 36: 561-566.

Morton, J. 1987. Rambutan. In Fruits of Warm Climates, edited by Morton, J. Miami: Julia J Morton. pp. 262-265.
Ng, S.K. \& Thamboo, S. 1967. Nutrient removal studies on Malaysian fruits - durian and rambutan. Malaysian Agricultural Journal 46: 164-183.

O'Hare, T.J. 1995. Postharvest physiology and storage of rambutan. Postharvest Biol. Technol. 6: 189-199.

Okonogi, S., Duangrat, C., Anuchpreeda, S., Tachakittirungrod, S. \& Chowwanapoonpohn, S. 2007. Comparison of antioxidant capacities and cytotoxicities of certain fruit peels. Food Chemistry 103: 839-846.

Palanisamy, U., Cheng, H.M., Masilamani, T., Subramaniam, T., Ling, L.T. \& Radhakrishnan, A.K. 2008. Rind of the rambutan, Nephelium lappaceum, a potential source of natural antioxidants. Food Chemistry 109: 54-63.

Ranganna, S. 1977. Manual of Analysis of Fruit and Vegetable Products. New Delhi: Tata MacGraw Hill Company Ltd. p. 1112.

Selvaraj, Y. \& Pal, D.K. 1984. Changes in the chemical composition and enzyme activity of two sapodilla (Manilkara zapota) cultivars during development and ripening. Journal of Horticultural Science 59: 275-281.

Siriphanich, J. 2003. Physiology and Postharvest Technology of Fruit and Vegetable. 5th ed. Ladyaow Chatuchak: Kasetsart University. p. 396.

Sirisompong, W., Jirapakkul, W. \& Klinkesorn, U. 2011. Response surface optimization and characteristics of rambutan (Nephelium lappaceum L.) kernel fat by hexane extraction. LWT - Food Science and Technology 44: 1946-1951.

Sturm, K., Koron, D. \& Stampar, F. 2003. The composition of fruit of different strawberry cultivars depending on maturity stage. Food Chemistry 83: 417-422.

Suhendi, A. \& Muhtadi, M. 2015. Potential activity of rambutan (Nephelium lappaceum L.) fruit peel extract as antidiabetic and antihypercholesterolemia. In The 2nd International Conference on Engineering Technology and Industrial Application, Surakarta. pp. 20-23.

Tee, E.S., Ismail, M., Mohd Nasir, A. \& Khatijah, I. 1997. Nutrient Composition of Malaysian Foods. Malaysian Food Composition Database Programme. Kuala Lumpur: Institute Medical for Research. p. 299.

Thitilertdecha, N., Teerawutgulrag, A. \& Rakariyatham, N. 2008. Antioxidant and antibacterial activities of Nephelium lappaceum L. extracts. LWT - Food Science and Technology 41: 2029-2035.

Tindall,H.D. 1994. Sapindaceous fruits: Botany and horticulture. In Horticultural Reviews. Vol. 16, edited by Janick, J. London: John Wiley \& Sons. pp. 143-196.

Wall, M.M. 2006. Ascorbic acid and mineral composition of longan (Dimocarpus longan), lychee (Litchi chinensis) and rambutan (Nephelium lappaceum) cultivars grown in Hawaii. Journal of Food Compoition and Analysis 19: 655-663.

Winayanuwattikun, P., Kaewpiboon, C., Piriyakananon, K., Tantong, S., Thakernkarnkit, W., Chulalaksananukul, W. \& Yongvanich, T. 2008. Potential plant oil feedstock for lipase-catalyzed biodiesel production in Thailand. Biomass and Bioenergy 32: 1279-1286.

Zee, F.T. 1993. Rambutan and pilinuts: potential crops of Hawaii. In New Crops, edited by Janick, J. \& Simon, J.E., New York: John Wiley and Sons Inc. pp. 461-465.

Faculty of Food Science and Technology

Universiti Putra Malaysia

43400 UPM Serdang, Selangor Darul Ehsan

Malaysia 
*Corresponding author; email: hasanah@upm.edu.my

Received: 17 November 2017

Accepted: 3 March 2018 